\title{
Follicle-forming cat thyroid cell lines synthesizing extracellular matrix and basal membrane components: a new tool for the study of thyroidal morphogenesis
}

\author{
C Tognella, U Marti, H J Peter ${ }^{1}$, H E Wagner ${ }^{2}$, C Glaser ${ }^{3}$, \\ J Kämpf ${ }^{4}$, F Simon ${ }^{4}$, H J Häuselmann ${ }^{5}$, M Paulsson ${ }^{5}$, C Ruchti $^{6}$, \\ M E Bürgi-Saville ${ }^{4}$, U Bürgi ${ }^{4}$ and $\mathbf{H}$ Gerber \\ Department of Clinical Chemistry, University Hospital, CH-3010 Berne, Switzerland \\ ${ }^{1}$ Division of Medicine, Anna Seiler, University Hospital, CH-3010 Berne, Switzerland \\ ${ }^{2}$ Clinic of Surgery, District Hospital, CH-3600 Thun, Switzerland \\ ${ }^{3}$ Visceral Surgery, University Hospital, CH-3010 Berne, Switzerland \\ ${ }^{4}$ Endocrine and Diabetes Division, University Hospital, CH-3010 Berne, Switzerland \\ ${ }^{5}$ M E Müller-Institute, University Hospital, CH-3010 Berne, Switzerland \\ ${ }^{6}$ Pathology, University Hospital, CH-3010 Berne, Switzerland \\ (Requests for offprints should be addressed to H Gerber)
}

\begin{abstract}
Interactions between follicular epithelial cells and extracellular matrix (ECM) are supposed to play an important role in the development and maintenance of thyroid tissue architecture. In the present study we have therefore investigated the synthesis of ECM components by a feline thyroid cell line which is able to form follicle-like structures in vitro, and also in v-ras-transfected and controltransfected sublines. Transfections were performed by lipofection with pZSR (viral Harvey ras gene; neo) and pSV2-neo (control, neo only) plasmids. We have adapted a semisolid culture system composed exclusively of polymerized alginate and therefore devoid of ECM components. Feline cells embedded in alginate gels as single cells and cultured for up to 90 days formed cell clusters within 10 days. Follicle-like structures were formed in the original cell lines and also in the v-ras- and controltransfected cells. Differences in proliferation rates were observed, the v-ras-transfected cells growing up to two to three times faster than the non-transfected cells. Immunostaining was done using rabbit first antibodies directed against mouse collagen IV, human fibronectin, laminin (tumor Engelbreth-Holm-Swarm laminin),
\end{abstract}

perlecan and other ECM components. For comparison, immunostaining was also performed on cryosections of nodular goiters of six hyperthyroid cats. The cell lines and their transfected clones stained strongly positive for collagen IV and fibronectin, and positively but less strongly for laminin and perlecan. The cat goiter tissue stained positively for collagen IV, laminin, perlecan, and fibronectin, and positive staining for S-laminin (containing the $\beta 2$-chain) was seen in blood vessel walls in this tissue.

In conclusion, cat cell lines grow three-dimensionally in alginate beads over several weeks, they form follicle-like structures and express the same ECM components as the native cat goiter tissue. Transfection with v-ras does increase proliferation rate, but does not fundamentally alter formation of follicle-like structures and ECM expression. Alginate gel culture is a promising new tool for the study of follicular morphogenesis, polarity, the expression pattern of ECM components and of the interaction between thyrocytes and ECM. It avoids interference caused by gels composed of ECM components.

Journal of Endocrinology (1999) 163, 505-514

\section{Introduction}

As extracellular structures, basal membranes (BMs) are thought to be involved in the regulation of cellular growth and tissue differentiation, and epithelial cells usually rest upon a BM. In addition, BMs show properties of selective barriers with respect to molecule permeability, and enhance epithelial cell attachment in vitro (for review see Farquhar 1982 and Paulsson 1992). Interactions between follicular epithelial cells and extracellular matrix (ECM) are supposed to play an important role in development and maintenance of thyroid tissue architecture. BMs are composed of the glycoprotein laminin and its associated polypeptide entactin, the heparan sulfate proteoglycan 
perlecan, as well as collagen type IV (CoIV), the major BM component. Several variants of these BM components have been described in different tissues (e.g. blood vessels, nerves, fat cells, lymphatics etc) (Kimura et al. 1980, Farquhar 1982, Paulsson \& Saladin 1989, Paulsson et al. 1991, Paulsson 1992).

In order to study in vitro thyroid differentiation, function and proliferation, various cell culture systems have been tested: monolayers (Ambesi-Impiombato et al. 1980, Ambesi-Impiombato \& Perrild 1989, Derwahl et al. 1990, Gerber et al. 1991a,b, Peter et al. 1991b, Dumont et al. 1992), three-dimensional systems using collagen gels (Yang et al. 1979, Garbi \& Wollman 1982, Garbi et al. 1984, Peter et al. 1987, 1991a-c, Toda \& Sugihara 1990, Toda et al. 1993), agarose gels (Kimura et al. 1980, Benya \& Shaffer 1982, Aydelotte et al. 1986a,b, Bruckner et al. 1989) and alginate beads (Kupchick et al. 1983, Guo et al. 1989, Häuselmann et al. 1994, Tognella et al. 1995, Glaser et al. 1996, Bürgi-Saville et al. 1997, 1998). Alginate has several advantages in comparison with the other systems. In comparison with monolayer culture it allows threedimensional growth of thyroid cells and follicles, imitating in vivo conditions much more closely. Being devoid of ECM components itself (other three-dimensional culture systems have used collagen or fibronectin gels) interference with immunohistochemical analyses of ECM components is avoided. Furthermore, by removing calcium with a chelating agent the alginate beads can be turned back into a liquid cell suspension, allowing harvesting of the cells for further experiments if required. Thus the alginate bead culture system offers an interesting alternative for investigations of the ECM, permitting, for example, the analysis of ECM components by immunohistochemistry, and also the investigation of the secretion of ECM components into the extracellular space by specific immunoprecipitation methods.

Thyroid follicular cell proliferation, differentiation and functions have been thoroughly investigated (for review see Ambesi-Impiombato \& Perrild 1989, Studer et al. 1989, Ericsson \& Fredriksson 1990, Dumont et al. 1992, Dumont \& Vassart 1994, Ekholm 1994, Gentile et al. 1994, Studer \& Gerber 1994, Peter et al. 1996). So far, much less but nevertheless fascinating research has been done on the structure and metabolism of ECM of thyroid tissue (Garbi \& Wollman 1982, Alquier et al. 1983, Garbi et al. 1984, 1988, 1990, Wadeleux et al. 1985, Demeure et al. 1992, Prabakaran et al. 1993, 1996, Vitale et al. 1993, 1994, 1995, Andre et al. 1994, Lemansky et al. 1994, Tognella et al. 1995, Arvan et al. 1997, Bürgi-Saville et al. 1997, 1998). Ultrastructural studies indicate that BM formation or maintenance can be achieved in cultures of thyroid cells (Alquier et al. 1983, Garbi \& Wollman 1982, Garbi et al. 1988). Cultured porcine cells have been shown to synthesize type I, II and IV collagens as well as a heparan sulfate glycosaminoglycan (Wadeleux et al. 1985) and also a laminin variant containing an $\alpha 2$-chain (merosin) (Andre et al. 1994). Synthesis of laminin, CoIV and fibronectin has been demonstrated in the thyroid epithelial cell line FRTL5 (Ambesi-Impiombato et al. 1980, Ambesi-Impiombato \& Perrild 1989) and also the deposition of the extracellular material at the basolateral surface of the cells and its organization into a BM (Garbi et al. 1988). We have recently demonstrated the maintenance of an ECM containing fibronectin, CoIV, laminin and perlecan both in FRTL 5 cells and in primary cultures of rat thyroid cells (Bürgi-Saville et al. 1998) and in primary cultures of normal human thyroid tissue, also in alginate beads (Bürgi-Saville et al. 1997).

In the present study we report the investigation of ECM synthesis by different feline thyroid cell lines (Romcat, Petcat) (Peter et al. 1987, 1991a-c, Gerber et al. 1991a,b, 1994) and v-ras-transfected sublines. For transfection, we have introduced the pZSR plasmid harboring the viral Harvey ras gene or the pSV2-neo plasmid only (as control) into the Romcat cell line (Gerber et al. 1991a,b, 1994). Embedded into alginate gel beads, three-dimensional growth of the cells could be observed. The cell clusters and follicle-like structures growing out from the cat cells were able to synthesize different ECM proteins such as CoIV, laminin, perlecan and fibronectin. We also investigated whether there is an evident connection between follicleforming capacity and ECM component production. Moreover, the relationship between ECM production, cell proliferation (measured by staining of the Ki-67 cell proliferation-associated antigen) and transfection status has been examined.

\section{Materials and Methods}

\section{Thyroid tissue, cell lines and culture conditions}

Thyroid tissue of hyperthyroid cats (Peter et al. 1987, Gerber et al. 1994) was obtained from Dr M E Peterson, Cornell University, New York, NY, USA. Different cell lines have been established from clinically wellcharacterized toxic nodular cat goiters and characterized as described (Peter et al. 1987, 1991a-c, Gerber et al. 1991a,b, 1994) (Table 1). In this study, we mainly used the Romcat cell line and eight v-ras-transfected sublines as well as two sublines transfected only with pSV2-neo (see below) (Table 1).

Cells were cultured as described (Peter et al. 1987, 1991a-c, Gerber et al. 1991a,b) in Coon's modified Ham F-12 medium (Seromed, Biochrom KG, Berlin, Germany), supplemented initially with 5\%, in later experiments with $1 \%$ newborn calf serum (Seromed) and six hormones, i.e. insulin, $10 \mu \mathrm{g} / \mathrm{ml}$ (Sigma, Division of Fluka Chemicals, Buchs, Switzerland), transferrin, $5 \mu \mathrm{g} / \mathrm{ml}$ (Sigma), somatostatin, $10 \mathrm{ng} / \mathrm{ml}$ (Sigma), glycyl-Lhistidyl-L-lysine, $10 \mathrm{ng} / \mathrm{ml}$ (Sigma), hydrocortisone, $3 \cdot 2 \mathrm{ng} / \mathrm{ml}$ (Sigma), thyrotropin from bovine pituitary (Sigma) at a concentration of $0.1 \mathrm{mU} / \mathrm{ml}$. Penicillin, 
Table 1 Characteristic features of cell lines tested

\begin{tabular}{|c|c|c|c|c|c|}
\hline & Thyroglobulin ${ }^{1}$ & Cytokeratin $^{1}$ & Vimentin $^{1}$ & Morphology & Follicle-forming capacity \\
\hline \multicolumn{6}{|l|}{ Cell type } \\
\hline Petcat 1 & + & $(+)$ & + & Epithelial & + \\
\hline Petcat 2 & + & + & + & Epithelial & + \\
\hline Petcat 3 & + & - & + & Mesencymal & - \\
\hline Petcat 4 & + & - & + & Mesenchymal & - \\
\hline Romcat, control non-transfected & + & + & + & Epithelial & ++ \\
\hline Romcat, pSV2-neo transfected, clone 1 & & & & Epithelial & ++ \\
\hline Romcat, pSV2-neo transfected, clone 2 & & & & Epithelial & ++ \\
\hline Romcat, pZSR transfected, clone 1 & & & & Epithelial & + \\
\hline Romcat, pZSR transfected, clone 2 & & & & Epithelial & + \\
\hline Romcat, pZSR transfected, clone 3 & & & & Epithelial & ++ \\
\hline Romcat, pZSR transfected, clone 4 & & & & Epithelial & +++ \\
\hline Romcat, pZSR transfected, clone 5 & & & & Epithelial & +++ \\
\hline Romcat, pZSR transfected, clone 6 & & & & Epithelial & + \\
\hline Romcat, pZSR transfected, clone 7 & & & & Epithelial & + \\
\hline Romcat, pZSR transfected, clone 8 & & & & Epithelial & + \\
\hline FRTL-5 & + & + & & Epithelial & - \\
\hline
\end{tabular}

${ }^{1}$ Positive (+) or negative (-) immunohistochemical staining with anti-thyroglobulin, anti-cytokeratin and anti-vimentin antibodies (Gerber et al. 1991b).

$100 \mathrm{IU} / \mathrm{ml}$ and streptomycin, $100 \mu \mathrm{g} / \mathrm{ml}$ were added as antibiotic agents. The culture medium was changed three times a week and cultured cells maintained at a temperature of $37^{\circ} \mathrm{C}$ in a humidified atmosphere with $5 \%$ carbon dioxide.

\section{Transfection procedure}

Transfection of Romcat cells either with the plasmid construct pZSR (kindly provided by Prof. R R Friis, University of Berne) harboring the viral Harvey ras gene (Remond et al. 1988) or the pSV2-neo plasmid (for transfection control purpose) was performed as described (Wagner et al. 1990a,b) with DOTAP (N-(1(2,3-dioleoyl-oxy)-propyl)-N,N,N-trimethyl-ammoniummethyl-sulfate) transfection reagent (Boehringer, Mannheim, Germany). In brief, Romcat cells were plated in $60 \mathrm{~mm}$ culture dishes and grown to subconfluency. The transfection reagent was prepared by dilution of $25 \mu \mathrm{l}$ DOTAP suspension with $75 \mu \mathrm{l}$ PBS. Five micrograms of pZSR plasmid or pSV2-neo plasmid suspended in $95 \mu \mathrm{l}$ PBS were added to this solution. The preparations were carefully mixed by gentle pipetting, and incubated for $10 \mathrm{~min}$ at room temperature. Finally, the mixtures were completed by adding $5 \mathrm{ml}$ culture medium. The thyroid cells were then exposed to the plasmid solution. After incubation for $4 \mathrm{~h}$, the transfection medium was replaced by fresh culture medium (Coon's modified F12 medium, supplemented with $5 \%$ fetal calf serum and the six hormones). The next day, the medium was changed again. Selection of successfully transfected cells (with acquired neomycin resistance) was performed by adding a medium containing Geneticin (400 $\mu \mathrm{g} / \mathrm{ml}$, Boehringer) (Wagner et al. 1990a,b). Test experiments, not presented here in detail, have shown that non-transfected feline cells die in medium containing Geneticin at a concentration of $400 \mu \mathrm{g} / \mathrm{ml}$. Eight different clones of the pZSR-transfected Romcat cell line and five different clones of the pSV2neo-transfected Romcat cell line were isolated, expanded and frozen for further investigations.

\section{Alginate culture technique}

Feline cells cultured as monolayers were, after trypsinization, prepared as a single cell suspension. Alginate beads were prepared as described (Häuselmann et al. 1994, Bürgi-Saville et al. 1997). In brief, $6 \times 10^{6}$ cells were suspended in $6 \mathrm{ml}$ of a solution of $1.2 \%$ alginate (sodium salt, Sigma) in $0.9 \% \mathrm{NaCl}$ (final concentration $10^{6}$ cells $/ \mathrm{ml}$ alginate). The cell suspension was dripped from a plastic syringe into $40 \mathrm{ml}$ of a slowly stirred sterile solution of $102 \mathrm{mM} \mathrm{CaCl} 2$ (Merck, Dietikon, Switzerland). Upon contact with the calcium solution, the alginate formed beads of approximately $2 \mathrm{~mm}$ in diameter which contained cat thyroid cells. The bead-forming process, i.e. the gelation of alginate, takes about $2 \mathrm{~min}$. Beads were allowed to polymerize completely in the $\mathrm{CaCl}_{2}$ solution for another $8 \mathrm{~min}$. Immediately after careful removal of the $\mathrm{CaCl}_{2}$ solution, beads were washed in $30 \mathrm{ml} \mathrm{0.9 \%} \mathrm{NaCl}$ or PBS solution three times for $5 \mathrm{~min}$, followed by a similar rinsing process in culture medium.

\section{Paraffin embedding process of alginate beads}

Alginate beads were washed in $0.05 \mathrm{M}$ Tris buffer, pH $7 \cdot 6$, supplemented with $7 \mathrm{mM} \mathrm{CaCl}_{2}$, and then fixed in buffered $4 \%$ formalin, $\mathrm{pH} 7 \cdot 4$, for $30 \mathrm{~min}$. Before embedding in paraffin, cells were washed in Tris buffer again. Overnight, beads were dehydrated in an automatic tissue processor (Histokinette Shandon Citadel 1000). In 

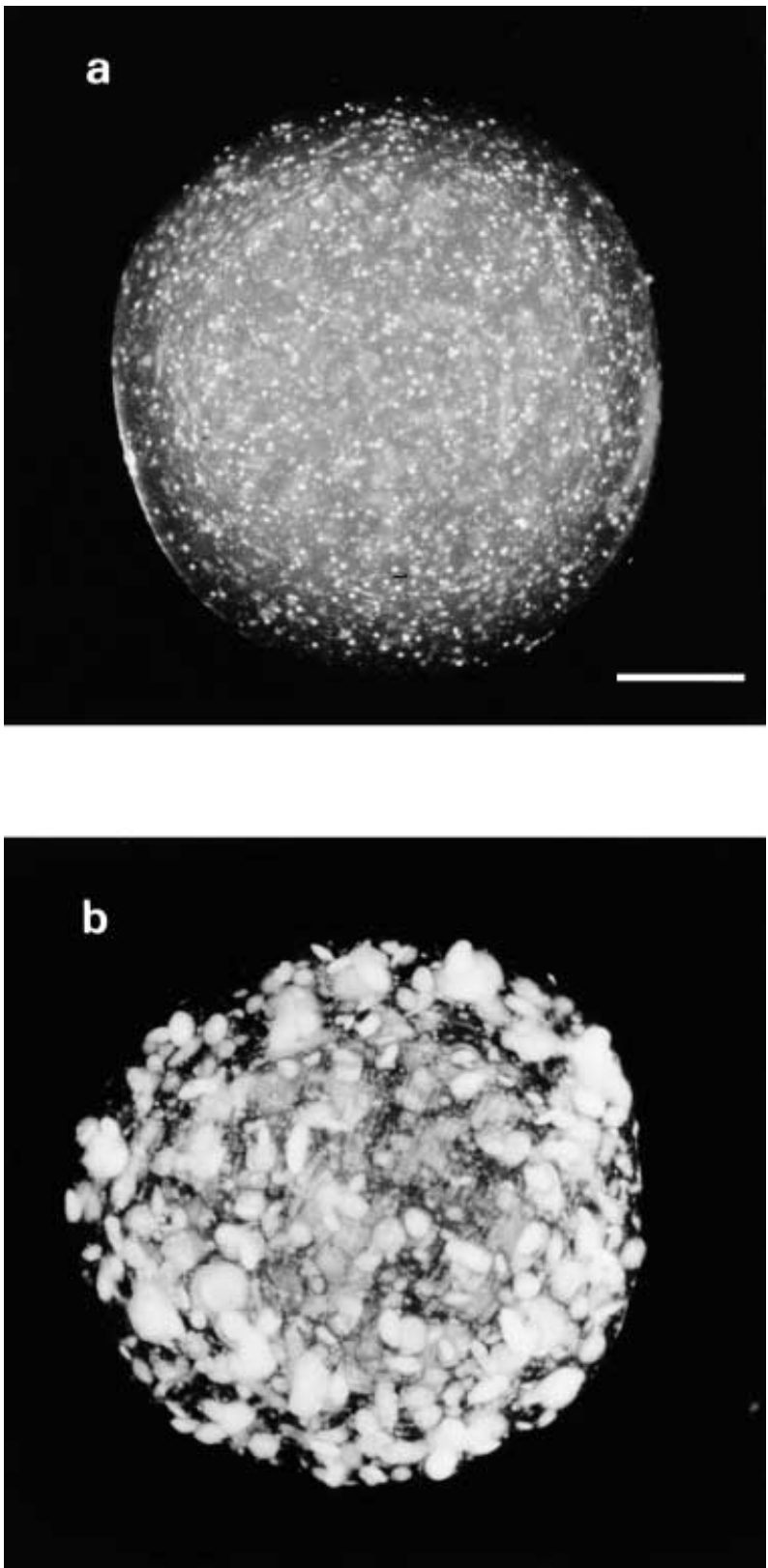

Figure 1 Proliferation patterns of two cat thyroid cell lines growing in alginate beads: (a) Petcat 4, non-transfected, 74 days of culture, (b) Romcat, v-ras-transfected, clone 2, 67 days of culture. Bar $500 \mu \mathrm{m}$.

specially adapted time cycles, samples passed through a series of ethanol solutions with ascending concentrations (50-95\%), followed by treatment with 2-propanol, xylol and paraffin, the whole preparation lasting $19 \mathrm{~h}$. After this pretreatment, the beads were embedded in paraffin (Histo-Comp, Vogel, Giessen, Germany). Sections of $2 \mu \mathrm{m}$ were prepared for immunohistochemical investigation.

\section{Immunohistochemical methods}

The sections were dewaxed with xylene and rehydrated through decreasing concentrations of ethanol. The sections were incubated overnight at room temperature with specific rabbit polyclonal primary antibodies to mouse laminin (Sigma, dilution 1:50), human fibronectin (Dako, Zug, Switzerland, dilution 1:250), mouse perlecan (kindly provided by Prof. J Hassell, University of Pittsburgh, PA, USA, dilution 1:100) and mouse CoIV (Becton Dickinson, Basel, Switzerland, dilution 1:250) (Studer et al. 1992, Bürgi-Saville et al. 1997). MIB-1, a monoclonal mouse antibody to the $\mathrm{Ki}-67$ proliferationassociated antigen (Dianova, Hamburg, Germany, dilution 1:50), was used as a cell proliferation marker. For this antigen, the slides were microwave pretreated in citric acid $(10 \mathrm{mM}, \mathrm{pH}$ 6) for $5 \mathrm{~min}$ at $750 \mathrm{~W}$. After $10 \mathrm{~min}$ cooling, this process was repeated twice followed by rinsing in water and PBS. After washing the slides with PBS for $15 \mathrm{~min}$, an alkaline phosphatase-coupled swine anti-rabbit immunoglobulin (Dako, dilution 1:50) was applied for $7 \mathrm{~h}$. For Ki-67 antigen detection, the monoclonal mouse antibody was followed by a biotinylated goat anti-mouse immunoglobulin (Dako, dilution 1:250). This complex was detected by an alkaline phosphataseconjugated ExtrAvidin (Sigma, dilution 1:250). Thereafter, slides were rinsed with PBS for $15 \mathrm{~min}$ and exposed to the substrate solution ( $3 \mathrm{mg}$ fast red TR salt (Sigma), $4 \mathrm{mg}$ naphthol AS-MX phosphate sodium salt (Sigma) and $1.5 \mathrm{mg}$ levamisole (Sigma), dissolved in $5 \mathrm{ml} 0.1 \mathrm{M}$ veronal acetate buffer, $\mathrm{pH}$ 8.3) for 20-30 min. The sections were rinsed in running tap water overnight and were counterstained with aqueous Ehrlich's hematoxylin. Finally, slides were sealed with Kaiser's glycerin gelatin (Merck). In controls for non-specific binding, the specific primary antibody was omitted in the first incubation step.

The expression of the $\mathrm{v}$-ras gene product in the v-ras-transfected cell was detected using a monoclonal antibody against ras protein (Oncogene Research Products, Cambridge, MA, USA). Monolayer cultures were fixed with methanol/acetic acid and incubated overnight with the primary antibody followed by a biotinylated goat anti-mouse immunoglobulin and ExtrAvidin as described above.

Immunofluorescent staining was performed in unfixed $6 \mu \mathrm{m}$ cryosections of nodular goiters of six hyperthyroid cats and in samples of cultured cells released from the alginate beads as previously described (Bürgi-Saville et al. 1997) and applied to eight-well microscope slides (Veenstra \& Dowale 1992). The cell samples were fixed for $10 \mathrm{~min}$ in acetone at room temperature. Following washing for $30 \mathrm{~min}$ in $50 \mathrm{mM}$ Tris, $150 \mathrm{mM}$ $\mathrm{NaCl}$, pH $7 \cdot 4$ containing 1\% BSA to block nonspecific binding sites, sections were incubated for $1 \mathrm{~h}$ with monoclonal primary antibodies as follows: human CoIV (diluted 1:250), and bovine laminin $\beta 2$-chain 

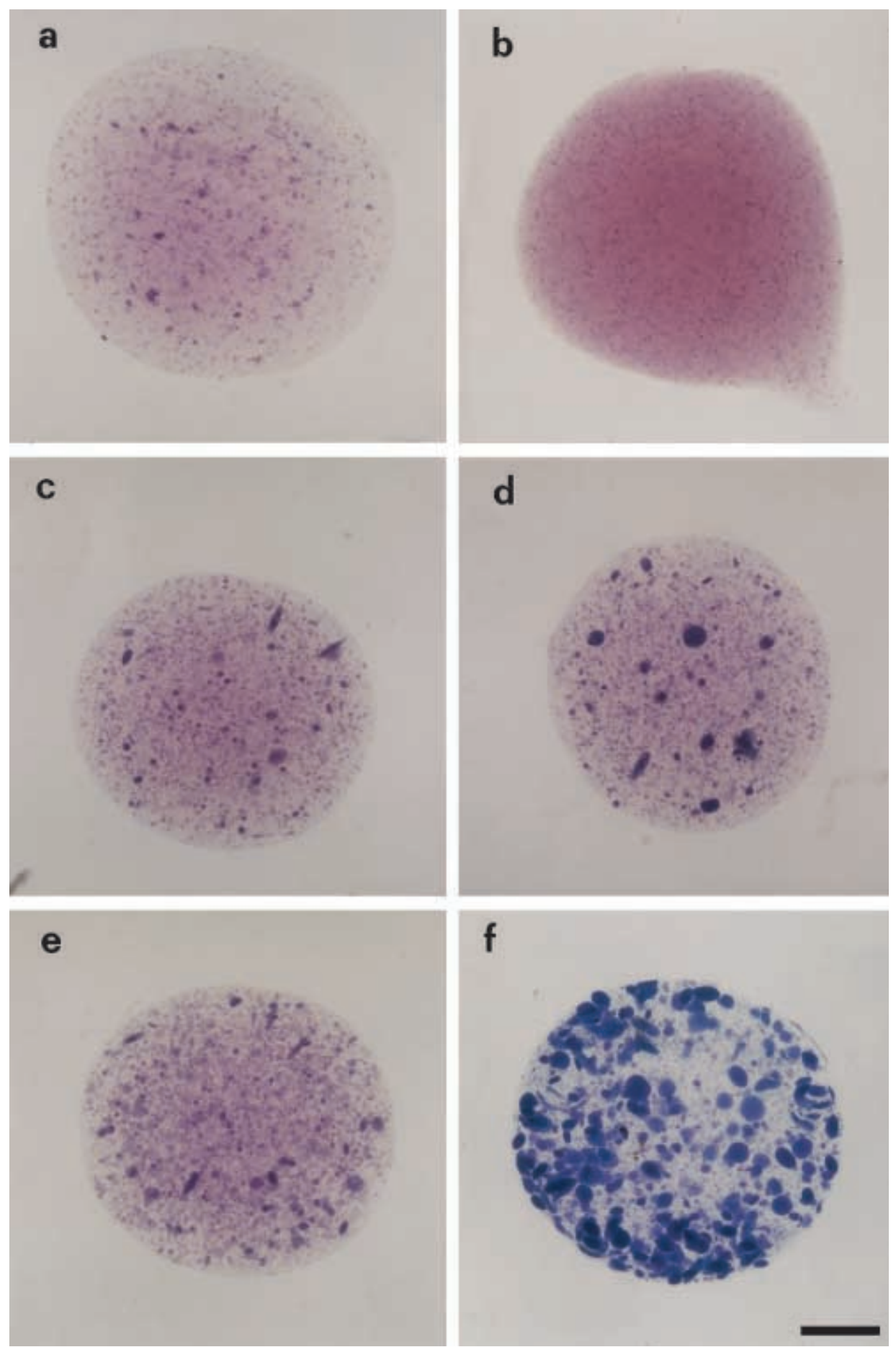

Figure 2 Cat thyroid cell lines growing in alginate beads, cultured with six-hormone medium, 5\% calf serum: (a) Romcat, non-transfected, 29 days of culture, (b) Petcat, clone 2, 41 days of culture,

(c) Romcat, v-ras-transfected, clone 7, 35 days of culture, (d) Romcat, v-ras-transfected, clone 7, 50 days of culture, (e) Romcat, $v$-ras-transfected, clone 2, 35 days of culture, (f) Romcat, v-ras-transfected, clone 2, 50 days of culture. Staining with crystal violet $0 \cdot 1 \%$. Bar $500 \mu \mathrm{m}$. 

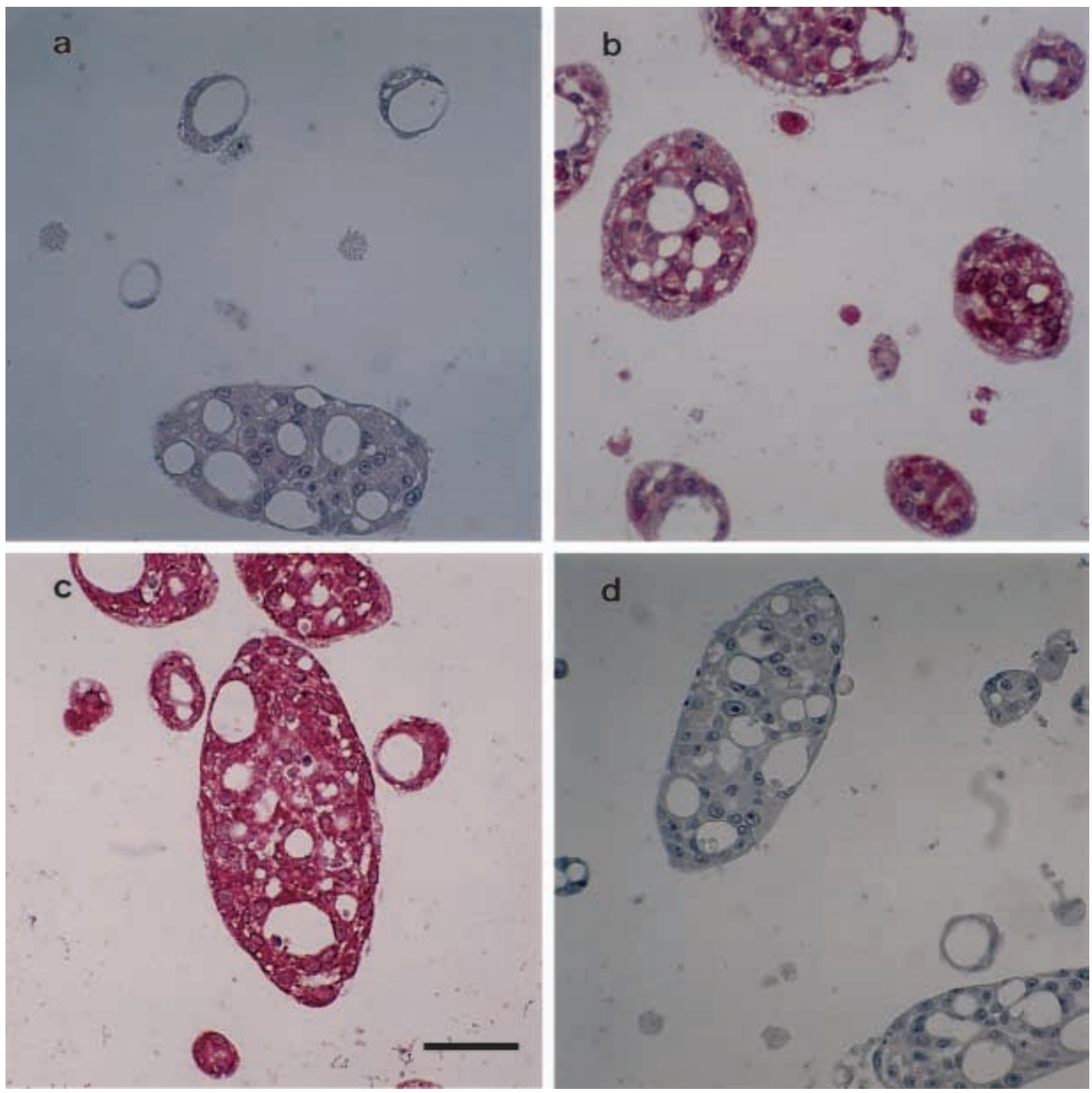

Figure 3 Immunohistochemical staining for ECM components in Romcat cell line, v-ras-transfected, clone 4, cultured with six-hormone medium, 5\% calf serum. (a) Laminin antibody (L9393), 11 days of culture, (b) fibronectin antibody, 18 days of culture,

(c) ColV antibody, 18 days of culture, (d) negative control. Bar $50 \mu \mathrm{m}$.

(S-laminin, 1:250) (developed by Dr Heinz Furthmayr and Dr Joshua Saves respectively), which were obtained from the Developmental Studies Hybridoma Bank maintained by the Department of Pharmacology and Molecular Sciences, Johns Hopkins University School of Medicine, USA and the Department of Biological Sciences, University of Iowa, IA, USA. Rabbit polyclonal antibodies to human fibronectin (Dako 1:250), mouse perlecan (as described above; 1:400) and mouse Engelbreth-Holm-Swarm (EHS) laminin (1:50) were also tested. The EHS laminin antibody was kindly provided by $\operatorname{Dr}$ A Lindblom, University of Berne. The sections were then incubated for $45 \mathrm{~min}$ with antimouse or anti-rabbit rhodamine-conjugated secondary antibodies (Dako, 1:25), washed and sealed using poly-DABCO. 
Table 2 Immunohistochemical staining

\begin{tabular}{|c|c|c|c|c|}
\hline & $\begin{array}{l}\text { Culture time } \\
\text { (days) }\end{array}$ & Antibody $^{1}$ & $\begin{array}{l}\text { Staining } \\
\text { intensity }\end{array}$ & $\begin{array}{l}\text { Follicle forming } \\
\text { capacity }\end{array}$ \\
\hline \multirow[t]{3}{*}{ Romcat non-transfected } & 35 & $\mathrm{~L}$ & ++ & ++ \\
\hline & & $\mathrm{F}$ & + & \\
\hline & & $\mathrm{C}$ & + & \\
\hline \multicolumn{5}{|l|}{ Romcat transfected } \\
\hline \multirow[t]{3}{*}{ Clone 1} & 35 & $\mathrm{~L}$ & +++ & + \\
\hline & & $\mathrm{F}$ & +++ & \\
\hline & & C & +++ & \\
\hline \multirow[t]{3}{*}{ Clone 2} & 33 & L & + & + \\
\hline & & $\mathrm{F}$ & ++ & \\
\hline & & C & ++ & \\
\hline \multirow[t]{3}{*}{ Clone 3} & 35 & $\mathrm{~L}$ & ++ & ++ \\
\hline & & $\mathrm{F}$ & ++ & \\
\hline & & C & +++ & \\
\hline \multirow[t]{3}{*}{ Clone 4} & 33 & $\mathrm{~L}$ & ++ & +++ \\
\hline & & $\mathrm{F}$ & +++ & \\
\hline & & C & +++ & \\
\hline \multirow[t]{3}{*}{ Clone 5} & 35 & $\mathrm{~L}$ & + & +++ \\
\hline & & $\mathrm{F}$ & ++ & \\
\hline & & $\mathrm{C}$ & +++ & \\
\hline \multirow[t]{3}{*}{ Clone 6} & 35 & $\mathrm{~L}$ & ++ & + \\
\hline & & $\mathrm{F}$ & +++ & \\
\hline & & C & $++/+++$ & \\
\hline \multirow[t]{3}{*}{ Clone 7} & 35 & $\mathrm{~L}$ & +++ & + \\
\hline & & $\mathrm{F}$ & $++/+++$ & \\
\hline & & C & ++++ & \\
\hline \multirow[t]{3}{*}{ Clone 8} & 33 & $\mathrm{~L}$ & $+/++$ & + \\
\hline & & $\mathrm{F}$ & ++ & \\
\hline & & $\mathrm{C}$ & +++ & \\
\hline
\end{tabular}

\section{Results and Discussion}

\section{Alginate culture system}

Feline cell lines embedded in alginate gel matrix as single cells were cultured for up to 90 days. They formed cell clusters within 10 days. Proliferation rates differed considerably between cell lines and their sublines. Romcat cells grew faster than Petcat cells and the v-ras-transfected Romcat sublines grew two to three times faster than the non-transfected Romcat cell line (Figs 1 and 2), as estimated from the labeling index for the proliferation-associated $\mathrm{Ki}-67$ antigen.

Petcat cells, which grow well in collagen gel (Peter et al. 1987, 1991a-c, Gerber et al. 1991a,b, 1994) and about as fast as Romcat cells, generally showed very low growth rates in alginate. Obviously Petcat cells depend-more than Romcat cells - on ECM components in the culture system for optimal three-dimensional growth in vitro.

\section{Expression patterns of ECM components}

Immunohistochemical studies showed that cat goiter tissue stained positively for CoIV, laminin (tumor EHS laminin), perlecan and fibronectin. S-laminin ( $\alpha \beta$-chain variant), selectively found in blood vessel walls in human tissue, was also found in vessel walls of cat thyroids.

In the studies of the cell lines, the following ECM components were investigated immunohistochemically: laminin (tumor EHS laminin), perlecan, CoIV and fibronectin. Results of immunohistochemical staining are shown in Fig. 3 and summarized in Table 2. Positive staining of variable intensity was seen for all four ECM components in the Romcat cell line and their v-rastransfected subclones. The Romcat cat cell lines express therefore the same ECM components as the native cat goiter tissue. Negative controls were completely unstained. For laminin, subclones 1 and 7 (with remarkable low follicle-forming capacity) showed a relatively high staining intensity. Medium staining intensity was found in non-transfected Romcat cells as well as in the transfected clones 3, 4, 6 and 8, whereas clone 2 and 5 showed low staining reaction. For fibronectin, non-transfected Romcat cells were the only cell type to stain only weakly positive, contrary to all transfected clones with medium (clones 2, 3,5 and 8) up to intensive staining properties. CoIV expression was found to a rather high degree in almost all 
transfected clones, i.e. clones 1 and 3-8. Clone 2 and non-transfected Romcat cells were the only ones with less intense staining. Perlecan expression was found in all clones examined (data not shown).

Immunohistochemical staining for ras in clone 5, with a high follicle-forming capacity and clones 6 and 7, with a low follicle-forming capacity, was found to be comparable. This suggests no direct correlation between the expression of v-ras and the follicle-forming capacity.

\section{Follicle formation}

The formation of follicle-like structures is illustrated in Figs 3 and 4 and summarized in Table 1. Immunohistochemical staining intensity of the ECM components was in general independent of the variable follicle-forming capacity in the Romcat cell line and their subclones, although subclones 1 and 7 , being the two transfected subclones with remarkable low follicle-forming capacity, showed a comparable high staining intensity with respect to EHS laminin. The two pSV2-neo-transfected cell lines studied showed comparable follicle-forming capacity.

\section{Transfection}

In the wider context of the question of ECM expression in the course of the neoplastic transformation, it was the aim of this study to find out whether ECM production and follicle formation by feline thyrocytes are altered with v-ras-gene expression. Transfection with v-ras did indeed increase the proliferation rate of the cell lines, but it did not fundamentally alter the expression pattern of the ECM components - as determined by immunohistochemistry and the formation of follicle-like structures (Tables 1 and 2 ). Whether the increased follicle-forming capacity found in clones 4 and 5 is due to the v-ras-transfection is not clear. The lack of a correlation between ras protein expression and the follicle-forming capacity suggests no direct effect. But the site of incorporation of the v-ras gene into the host genome may affect the follicle-forming capacity. However, this question can only be solved with an inducible v-ras expression system.

\section{Conclusions}

Cat thyroid cell lines - as isolated human normal and goiter cells (Bürgi-Saville et al. 1997), rat thyroid follicles (Glaser et al. 1996, Bürgi-Saville et al. 1997a), and some non-thyroidal cells (Guo et al. 1989, Häuselmann et al. 1994) - grow three-dimensionally in a calcium alginate gel matrix over several weeks. They form follicle-like structures and express the same ECM components as the native cat goiter tissue. However, cell lines which grow at similar rates in collagen gel may differ considerably in growth rates when cultured in alginate, possibly because some
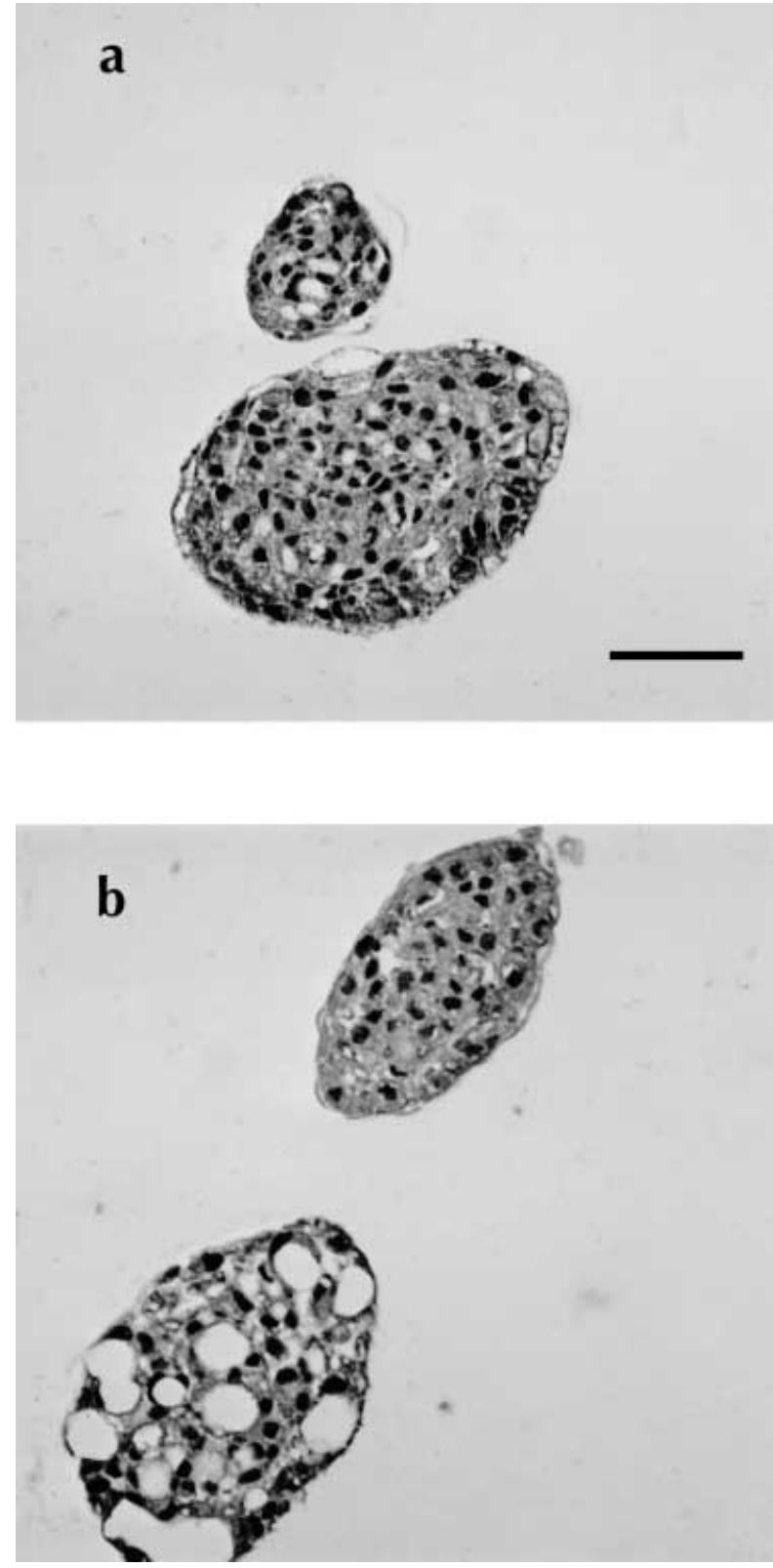

Figure 4 Follicle formation capacity. (a) Low capacity: Romcat, v-ras-transfected, clone 7, 33 days of culture, (b) high capacity: Romcat, v-ras -transfected, clone 4, 33 days of culture; (see also Table 2). Bar $50 \mu \mathrm{m}$.

depend more than others on ECM components in the culture system for optimal three-dimensional growth in vitro.

The expression pattern of ECM components, as determined by immunohistochemistry, was not correlated with the variable follicle-forming capacity of the cell lines, i.e. cell lines with a greater propensity to form follicles express 
the ECM components investigated to the same degree as cell lines with a lesser propensity to form follicles.

However, transfection with v-ras did indeed increase the proliferation rate of the cell lines, but it did not fundamentally alter the expression pattern of the ECM components and the formation of follicle-like structures. The preservation of the functional differentiation is in line with reports by others on the effect of viral Harvey ras and mutated human Harvey ras transfections (Nakagawa et al. 1987, Wynford-Thomas et al. 1990). However, both studies reported a decrease of cell proliferation, where we found in contrast an increase. This difference may be due to the cell lines used or the cell culture system used. The latter explanation would be also supported by the differences found in the growth behavior of the Petcat and Romcat cell lines in collagen gel (Peter et al. 1987, 1991a-c, Gerber et al. 1991a,b, 1994) and alginate beads.

As described before for non-thyroidal cells (Guo et al. 1989, Häuselmann et al. 1994), alginate bead gel culture is a promising new tool for the study of follicular morphogenesis, cell polarity, the expression pattern of ECM components and of the interaction between thyrocytes and ECM. Being free of ECM components, it avoids interference caused by gels composed of ECM components.

\section{Acknowledgements}

This work was supported by grants $31-34416.92$ and 32-039355.93 from the Swiss National Science Foundation. We thank Prof. R R Friis, Department of Clinical Research, University of Berne, for providing us with plasmid construct pZSR harboring the viral Harvey ras oncogene and a pSV2-neo construct.

\section{References}

Alquier C, Athouel-Haon AM, Mazzella E \& Michel-Bechet M 1983 Basement membrane maintenance in cultures of isolated thyroid follicles. Biology of the Cell 49 183-186.

Ambesi-Impiombato FS \& Perrild H (Eds) 1989 FRTL-5 today. Excerpta Medica International Congress Series 818 1-240.

Ambesi-Impiombato FS, Parks LAM \& Coon HG 1980 Cultures of hormone dependent functional epithelial cells from rat thyroids. Proceedings of the National Academy of Sciences of the USA 77 3455-3459.

Andre F, Filippi P \& Feracci H 1994 Merosin is synthesized by thyroid cells in primary culture irrespective of cellular organization. Journal of Cell Sciences 107 183-193.

Arvan P, Kim PS, Kuliawat R, Prabakaran D, Muresan Z, Yoo SE \& Hossain SA 1997 Intracellular protein transport to the thyrocyte plasma membrane: potential implications for thyroid physiology. Thyroid 7 89-105.

Aydelotte MB, Schleyerbach R, Zeck BJ \& Kuettner KE $1986 a$ Articular chondrocytes cultured in agarose gel for study of chondrocytic chondrolysis. Articular and Cartilage Biochemistry 235-256.
Aydelotte MB, Schleyerbach R, Zeck BJ \& Kuettner KE 1986 b Clonal analysis of the population of chondrocytes from the swarm rat condrosarcoma in agarose culture. Journal of Orthopedic Research 4 427-436.

Benya PD \& Shaffer JD 1982 Dedifferentiated chondrocytes reexpress the dedifferentiated collagen phenotype when cultured in agarose gel. Cell 30 215-224.

Bruckner P, Hörler I, Mendler M, Houze Y, Winterhalter KH, Eich-Bender SG \& Spycher MA 1989 Induction and prevention of chondrocyte hypertrophy in culture. Journal of Cell Biology 109 2537-2545.

Bürgi-Saville ME, Gerber H, Peter HJ, Paulsson M, Aeschlimann D, Glaser C, Kaempf J, Ruchti C \& Bürgi U 1997 Expression patterns of extracellular matrix components in native and cultured human thyroid tissue and in human toxic adenoma tissue. Thyroid 7 347-356.

Bürgi-Saville ME, Reut B, Gerber H, Peter HJ, Paulsson M, Kaempf J, Simon F, Marti U, Gerber H \& Bürgi U 1998 Alginate gel culture allows the retention of extracellular matrix and follicular structure of rat thyroid tissue but does not lead to the formation of follicles by FRTL-5 cells. Thyroid 8 1147-1155.

Demeure MJ, Damsky CH, Elfman F, Goretzky PE, Wong MG \& Clark OH 1992 Invasion by cultured human follicular thyroid cancer correlates with increased beta 1 integrins and production of proteases. World Journal of Surgery 16 770-776.

Derwahl M, Studer H, Huber G, Gerber H \& Peter HJ 1990 Intercellular propagation of individually programmed growth bursts in FRTL-5 cells. Implications for interpreting growth factor actions. Endocrinology 127 2104-2110.

Dumont JE \& Vassart G 1994 Thyroid regulation. In Endocrinology, edn 3, vol 1, ch 35, pp 543-559. Ed LJ DeGroot. Philadelphia, London, Toronto, Montreal, Sidney, Tokyo: WB Saunders Company.

Dumont JE, Lamy F, Roger P \& Maenhaut C 1992 Physiological and pathological regulation of thyroid cell proliferation and differentiation by thyrotropin and other factors. Physiology Reviews $\mathbf{7 2}$ 667-697.

Ekholm R 1994 Anatomy and development. In Endocrinology, edn 3, vol 1, ch 33, pp 507-516. Ed. LJ DeGroot. Philadelphia, London, Toronto, Montreal, Sidney, Tokyo: WB Saunders Company.

Ericson LE \& Fredriksson G 1990 Phylogeny and ontogeny of the thyroid gland. In The Thyroid Gland. Comprehensive Endocrinology, pp 1-35. Ed MA Greer. New York: Raven Press.

Farquhar MG 1982 Cell Biology of Extracellular Matrix, pp 335-378. New York: Plenum Press.

Garbi C \& Wollman SH 1982 Basal lamina formation on thyroid epithelia in separated follicles in suspension culture. Journal of Cell Biology 94 489-492.

Garbi C, Nitsch L \& Wollman SH 1984 Embedding in a collagen gel stabilizes the polarity of epithelial cells in thyroid follicles in suspension culture. Experimental Cell Research 151 458-465.

Garbi C, Zurzolo C, Bifulco M \& Nitsch L 1988 Synthesis of extracellular matrix glycoproteins by a differentiated thyroid epithelial cell line. Journal of Cellular Physiology 135 39-46.

Garbi C, Colletta G, Cirafici AM, Marchisio PC \& Nitsch L 1990 Transforming growth factor-beta induces cytoskeleton and extracellular matrix modifications in FRTL-5 thyroid epithelial cells. European Journal of Cell Biology 53 281-289.

Gentile F, Di Lauro R \& Salvatore G 1994 Biosynthesis and secretion of thyroid hormones. In Endocrinology, edn 3, vol 1, ch 34, pp 517-542. Ed LJ DeGroot. Philadelphia, London, Toronto, Montreal, Sidney, Tokyo: WB Saunders Company.

Gerber H, Peter HJ, Asmis L \& Studer H 1991a Thyroid cell lines in research on goitrogenesis. Thyroidology 3 115-118.

Gerber H, Peter HJ, Bösiger J, Studer H, Drews R, Ferguson DC, Peterson ME \& Becker DV $1991 b$ Different continuous cell lines from adenomatous feline goiters widely differ in morphologic, 
functional and growth parameters. In Progress in Thyroid Research, pp 541-544. Eds A Gordon, J Gross \& G Hennemann. Rotterdam: A. A. Balkema Publishers.

Gerber H, Peter HJ, Peterson ME \& Ferguson DC 1994 Etiopathology of feline toxic nodular goiter. Veterinary Clinics of North America: Small Animal Practice 24 541-565.

Glaser Ch, Gerber H, Ruchti C, Bürgi U, Büchler MW \& Peter HJ 1996 Iodine increases follicular size in cultured organoids from newborn rat thyroids. Journal of Endocrinological Investigation 19 (Suppl) 65 (Abstract 130).

Guo J, Jourdian GW \& McCallum DK 1989 Culture and growth characteristics of chondrocytes encapsulated in alginate beads. Connective Tissue Research 19 277-297.

Häuselmann HJ, Russell JF, Mok SS, Schmid TM, Block JA, Aydelotte MB, Kuettner KE \& Thonar E 1994 Phenotypic stability of bovine articular chondrocytes after long-term culture in alginate beads. Journal of Cell Science 107 17-27.

Kimura JH, Hardingham T \& Hascall VC 1980 Assembly of newly synthesized proteoglycan and link protein into aggregates in cultures of chondrosarcoma chondrocytes. Journal of Biological Chemistry 255 7134-7143.

Kupchik HZ, Langer RS, Haberern C, El Derny S \& O'Brian M 1983 A new method for the three-dimensional in vitro growth of human cancer cells. Experimental Cell Research 147 454-460.

Lemansky P, Popp MG, Tietz J \& Herzog V 1994 Identification of iodinated proteins in cultured thyrocytes and their possible significance for thyroid hormone formation. Endocrinology 135 $1566-1575$.

Nakagawa T, Mabry M, De Bustros A, Ihle JN, Nelkin BD \& Baylin SB 1987 Introduction of v-Ha-ras oncogene induces differentiation of cultured human medullary thyroid carcinoma cells. Proceedings of the National Academy of Sciences of the USA 84 5923-5927.

Paulsson M 1992 Basement membrane proteins: structure, assembly, and cellular interactions. Critical Reviews in Biochemistry and Molecular Biology 27 93-127.

Paulsson M \& Saladin K 1989 Mouse heart laminin. Purification of the native protein and structural comparison with EngelbrethHolm-Swarm tumor laminin. Journal of Biological Chemistry 264 18726-18732.

Paulsson M, Saladin K \& Engvall E 1991 Structure of laminin variants. Journal of Biological Chemistry 266 17545-17551.

Peter HJ, Gerber H, Studer H, Peterson ME \& Becker DV 1987 Autonomy of growth and of iodine metabolism in hyperthyroid feline goiters transplanted onto nude mice. Journal of Clinical Investigation 80 491-498.

Peter HJ, Gerber H, Studer H, Groscurth P \& Zakarija M 1991a Thyroid cell lines forming follicle-like lumina in vitro. In Progress in Thyroid Research, pp 579-582. Eds A Gordon, J Gross \& G Hennemann. Rotterdam: A. A. Balkema Publishers.

Peter HJ, Gerber H, Studer H, Groscurth P \& Zakarija M $1991 b$ Comparison of FRTL-5 cell growth in vitro with that of xenotransplanted cells and the thyroid of the recipient mouse. Endocrinology 128 211-219.

Peter HJ, Gerber H, Studer H, Peterson ME, Becker DV \& Groscurth P 1991c Autonomous growth and function of cultured thyroid follicles from cats with spontaneous hyperthyroidism. Thyroid 1 331-337.

Peter HJ, Bürgi U \& Gerber H 1996 Pathogenesis of nontoxic diffuse and nodular goiter. In Werner's and Ingbar's The Thyroid, edn 7, ch 78, pp 890-895. Eds LE Braverman \& R Utiger. Philadelphia: JB Lippincott.

Prabakaran D, Kim PS, Kim K-R \& Arvan P 1993 Polarized secretion of thrombospondin is opposite to thyroglobulin in thyroid epithelial cells. Journal of Biological Chemistry 268 9041-9048.

Prabakaran D, Kim PS, Dixit VM \& Arvan P 1996 Oligomeric assembly of thrombospondin in the endoplasmic reticulum of thyroid epithelial cells. European Journal of Cell Biology 70 134-141.
Redmond SMS, Reichmann E, Müller RG, Friis RR, Groner B \& Hynes NE 1988 The transformation of primary and established mouse mammary epithelial cells by p21-ras is concentration dependent. Oncogene 2 259-265.

Studer H \& Gerber H 1994 Multinodular goiter. In Endocrinology, edn 3, vol 1, ch 46, pp 769-782. Ed LJ DeGroot. Philadelphia, London, Toronto, Montreal, Sidney, Tokyo: WB Saunders Company.

Studer H, Peter HJ \& Gerber H 1989 Natural heterogeneity of thyroid cells: the basis for understanding thyroid function and nodular goiter growth. Endocrine Reviews 10 125-135.

Studer H, Gerber H, Zbären J \& Peter HJ 1992 Histomorphological and immuno-histochemical evidence that human nodular goiters grow by episodic replication of multiple clusters of thyroid follicular cells. Journal of Clinical Endocrinology and Metabolism 75 1151-1158.

Toda S \& Sugihara H 1990 Reconstruction of thyroid follicles from isolated porcine follicle cells in three-dimensional collagen gel culture. Endocrinology 126 2027-2034.

Toda S, Yonemitsu N, Minami Y \& Sugihara H 1993 Plural cells organize thyroid follicles through aggregation and linkage in collagen gel culture of porcine follicle cells. Endocrinology 133 914-920.

Tognella C, Peter HJ, Wagner H, Kaempf J, Simon F, Glaser C, Ferguson DC, Peterson ME, Häuselmann HJ, Paulsson M, Ruchti C, Bürgi-Saville ME, Bürgi U \& Gerber H 1995 Follicle forming cat thyroid cell lines synthesizing extracellular matrix and basal membrane components: a new tool for the study of thyroidal morphogenesis. Thyroid 5 (Suppl 1) S-169 (Abstract 336).

Veenstra H \& Dowale EB 1992 Multiwell cell monolayers for immunocytochemistry. An alternative to cytocentrifuge preparations. Journal of Immunological Methods 146 257-258.

Vitale M, Bassi V, Fenzi GF, Macchia PE, Salzano S \& Rossi G 1993 Integrin expression in thyroid cells from normal glands and nodular goiters. Journal of Clinical Endocrinology and Metabolism 76 1575-1579.

Vitale M, Bassi V, Illario M, Fenzi GF, Casamassima A \& Rossi G 1994 Loss of polarity and de novo expression of the beta 1 family of integrins in thyroid tumors. International Journal of Cancer $\mathbf{5 9}$ $185-190$.

Vitale M, Casamassima A, Illario M, Bassi V, Fenzi GF \& Rossi G 1995 Cell-to-cell contact modulates the expression of the beta 1 family of integrins in primary cultures of thyroid cells. Experimental Cell Research 220 124-129.

Wadeleux P, Nusgens B, Foidart JM, Lapiere C \& Winand R 1985 Synthesis of basement membrane components by differentiated thyroid cells. Biochimica et Biophysica Acta 846 257-264.

Wagner HE, Joyce AD, Beatrice K \& Summerhayes IC 1990a Ras induced lesions in a heterotopic mouse bladder. Oncogene $\mathbf{5}$ 557-563.

Wagner HE, Steele G \& Summerhayes IC 1990b Preneoplastic lesions induced by myc and src oncogenes in reconstituted mouse bladder. Surgery 108 146-153.

Wynford-Thomas D, Bond JA, Wyllie FS, Burns JS, Williams ED, Jones T, Sheer D \& Lemoine NR 1990 Conditional immortalization of human thyroid epithelial cells: a tool for analysis of oncogene action. Molecular and Cellular Biology 10 5365-5377.

Yang J, Richards J, Bowam P, Guzman R, Enami J, McCormick K, Hamamoto S, Pitelka D \& Nandi S 1979 Sustained growth and three-dimensional organisation of primary mammary tumor epithelial cells embedded in collagen gels. Proceedings of the National Academy of Sciences of the USA $\mathbf{7 6} 4301-4305$.

\section{Received 12 October 1998}

Revised manuscript received 12 July 1999

Accepted 20 July 1999 